\title{
Evaluating remote sensing indices as potential productivity and stand quality indicators for Pinus radiata plantations
}

\author{
Avaliando índices de sensoriamento remoto como indicadores de \\ produtividade potencial e indicadores de qualidade para plantios de Pinus \\ radiata
}

Vitor Vannozzi Brito ${ }^{1}$ (D), Rafael Alejandro Rubilar ${ }^{2}$ (D), Rachel Louise Cook ${ }^{3}$ (D), Otávio Camargo Campoe ${ }^{4}$ (D), David Robert Carter ${ }^{5}$, Oscar Mardones ${ }^{6}$
1Departamento de Ciências Florestais, Escola Superior de Agricultura “Luiz de Queiroz" - ESALQ, Universidade de São Paulo - USP, Piracicaba, SP, Brasil
${ }^{2}$ Cooperativa de Productividad Forestal - FPC, Departamento Silvicultura, Facultad de Ciencias Forestales, Universidad de Concepción - UdeC, Concepción, Chile
${ }^{3}$ Forest Productivity Cooperative - FPC, Department of Forestry and Environmental Conservation, North Carolina State University - NCSU, Raleigh, NC, United States
${ }^{4}$ Forest Productivity Cooperative - FPC, Departamento de Ciências Florestais, Universidade Federal de Lavras - UFLA, Lavras, MG, Brasil
${ }^{5}$ Forest Productivity Cooperative - FPC, Department of Forest Resources and Environmental Conservation, Virginia Tech, Blacksburg, VA, United States
${ }^{6}$ Forestal Mininco S.A., CMPC. Los Angeles, Chile

\begin{abstract}
How to cite: Brito, V. V., Rubilar, R. A., Cook, R. L., Campoe, O. C., Carter, D. R. (2021). Evaluating remote sensing indices as potential productivity and stand quality indicators for Pinus radiata plantations. Scientia Forestalis,
\end{abstract} 49(129), e3316. https://doi.org/10.18671/scifor.v49n129.08

\begin{abstract}
The objective of the present research was to evaluate the use of several spectral vegetation indices (SVIS), including NDVI, SAVI, SR and RSR, obtained from Landsat 7 images, as potential predictors of forest productivity of radiata pine stands. We aimed to evaluate relationships between the variations in stand volume and SVIs over time and the effect of early weed control on stand growth response. We evaluated a large-scale silviculture experiment located at the Central Valley of Chile, since its establishment until 12 years of age, where weed control showed to be the major silvicultural response. Forest inventory measurements were made annually and local equations were used to estimate stand volume. Significant and highly significant correlation was found among SVI's and stand productivity parameters. The best relationship was found between NDVI and stand cumulative volume (R-adj=0.92, p-value $<0.0001, \mathrm{RMSE}=0.03$ ), but SR and RSR were able to better track productivity and the major weed control effect on stand volume growth over time. SVIs' coefficient of variation estimates were correlated with estimates of stand productivity variability but no significant relationships were established to provide an index of stand quality due to the sensor spatial resolution and plot sizes. SVIs may serve as important tools to monitor forest growth and high-resolution imagery may provide valuable estimates of stand variability for inventory assessment or as a support tool for growth and yield models.
\end{abstract}

Keywords: Remote sensing; Vegetation indices; Planted forests; Pinus radiata; Quality control.

\section{Resumo}

Esta pesquisa teve como objetivo avaliar índices espectrais de vegetação (IEVs), incluindo NDVI, SAVI, SR e RSR gerados a partir de imagens Landsat 7, como estimadores potenciais da produtividade em povoamentos de Pinus radiata. Buscou-se avaliar as relações entre as variações do volume do

Financial support: Forest Productivity Cooperative (FPC) and Forestal Mininco S.A.

Conflict of interest: Nothing to declare.

Corresponding author: vitorvannozzi@gmail.com

Received: 18 March 2019.

Accepted: 06 May 2020.

Editor: Paulo Henrique Müller Silva.

(c) (i) This is an Open Access article distributed under the terms of the Creative Commons Attribution License, which permits unrestricted use,

c) distribution, and reproduction in any medium, provided the original work is properly cited. 
povoamento e dos IEVs calculados ao longo do tempo, além do efeito da capina precoce na resposta em crescimento do povoamento. Foi avaliado um experimento de silvicultura de grande escala localizado no Vale Central do Chile, desde seu estabelecimento até os 12 anos de idade, onde o controle de ervas daninhas mostrou-se como o principal fator de resposta silvicultural. Inventários florestais foram realizados anualmente e equações locais foram utilizadas para estimar o volume do povoamento. Correlações significativas e altamente significativas foram encontradas entre os índices estimados e os parâmetros de produtividade do sítio. O melhor modelo foi ajustado a partir do NDVI para o volume acumulado do plantio $(R=0.92$, $p$-value $<0.0001$, RMSE $=0.03)$, porém SR e RSR refletiram de melhor maneira a produtividade e o efeito do controle de plantas daninhas no crescimento do povoamento ao longo do tempo. Coeficientes de variação dos IEVs foram correlacionados com estimativas de variabilidade da produtividade do povoamento, sem, entretanto, permitir o estabelecimento de relações significativas para fornecer um índice de qualidade do povoamento devido à resolução do sensor e ao tamanho das parcelas. Os IEVs podem servir como importantes ferramentas para monitorar o crescimento da floresta e imagens de alta resolução podem fornecer valiosas estimativas da variabilidade do povoamento para a avaliação de inventário, bem como servir como ferramenta de suporte para modelos de crescimento e produção.

Palavras-chave: Sensoriamento remoto; Índices de vegetação; Floresta plantada; Pinus radiata; Controle de qualidade.

\section{INTRODUCTION}

Leaf Area Index (LAI) is defined as the amount of foliage per unit ground surface per area. It is an important physiological parameter which is related to many processes associated with forest ecosystems such as light interception, evapotranspiration, nutrient cycling and photosynthesis (Chen \& Cihlar, 1996; Tian et al., 2007; Almeida et al., 2015). Leaf area is also dependent on climatic conditions, site factors, stand density at early ages, thus LAI can be understood as a measurement of site occupancy, integrating many elements. As a result, responses in LAI to fertilization have been observed, weed control and thinning, and consequently, in carbon accumulation and tree growth (Peduzzi et al., 2012). Since LAI integrates many elements, LAI and forest productivity are usually positively related (Dalla Tea \& Jokela, 1992; Beets \& Whitehead, 1996). Vose \& Allen (1988), for example, studied this relationship for Pinus taeda stands and a unit of LAl produced an average of $7.3 \mathrm{~m}^{3} / \mathrm{ha} / \mathrm{yr}$ and similar relationships have been presented for other species (Battaglia et al., 1998; Rubilar et al., 2013).

Due to the importance of LAI to various ecological processes, substantial research has focused on the development of tools to indirectly estimate LAI (Francis et al., 1969; Jordan, 1969). One of these tools is remote sensing which has been used successfully to estimate LAI values (Flores, 2003; Rubilar et al., 2018; Berger et al., 2019). The basis of remote sensing to estimate LAI is based on the selective absorption of radiation by the canopy, which presents a distinguishing pattern for reflectance of radiation in the red wavelength $(630-690 \mathrm{~nm})$ that is absorbed by chlorophyll pigments of green leaves, and the near infrared radiation (NIR - 770$900 \mathrm{~nm}$ ) that is scattered by internal leaf structure (Running et al., 1986; Flores et al., 2006) being proportional to foliage stand biomass.

In order to characterize canopy from remote sensing data, numerous spectral vegetation indices (SVIs), including Red and Near Infra-Red (NIR) reflectance, have been proposed to empirically estimate LAl and biomass (Xavier \& Vettorazzi, 2004; Almeida et al., 2015). Usually these indices combine spectral bands by simple mathematical ratios of individual bands or differences between bands (Tian et al., 2007). One of the pioneer SVIs, the near-infrared/red ratio (or Simple Ratio - SR), developed by Jordan (1969) to estimate leaf area index in a tropical rainforest canopy, has been found highly related to LAI in coniferous natural and planted forests (Running et al., 1986; Flores et al., 2006). However, SR index may present some limitations when saturation occurs at high stand LAI values (Le Maire et al., 2012) or when understory is present in abundance (Stenberg et al., 2004). In order to avoid this limitation Brown et al. (2000) developed the reduced simple ratio index (RSR), which includes a middle infrared spectral band in the calculation, aimed at reducing the effect of background reflectance and increasing the sensitivity to changes in LAI. Results from Stenberg et al. (2004), 
Brown et al. (2000), and Tian et al. (2007) suggest that RSR presented better correlations with LAI than SR for coniferous stands in Finland, Canada and China, respectively.

Another very important spectral vegetation index that has been widely used is the Normalized Difference Vegetation Index (NDVI), which is a normalized ratio of the NIR and red bands (Rouse et al., 1973). Several studies in different types of forest formations have related NDVI to: LAl, biomass and productivity (Yang et al., 2017). However, NDVI also presents some limitations such as: a) saturation when LAI has values higher than 2 or 3 , b) its sensitivity to soil variation by color and/or humidity (Viganó et al., 2011). As a result of these restrictions, the Soil-Adjusted Vegetation Index (SAVI) (Huete, 1988) has been proposed, which considers a correction factor (L) for soil effects on vegetation reflectance. Huete (1988) suggested an optimal value of $L=0.5$ to minimize these variations. Almeida et al. (2015) found a good relationship between SAVI and LAl; however, the results suggest that the L constant has to be reviewed and adjusted to local-specific values in order to achieve an accurate relationship. Since SVIs are related to LAI, which has been extensively related to forest productivity, the objective of this study was to evaluate the potential direct use of spectral vegetation indices, using Landsat 7 imagery, on explaining Pinus radiata annual productivity from the stand establishment until the age of 12 years and to evaluate their direct potential value as a complementary tool for improving inventory and/or dynamic variables of potential use on hybrid G\&Y models.

\section{MATERIALS AND METHODS}

\subsection{Study Area}

The study site, located at the Central Valley of Chile $\left(37^{\circ} 10^{\prime} 42^{\prime \prime} S, 72^{\circ} 15^{\prime} 47^{\prime \prime}\right.$ W), was described as a Dry Sand site in detail by Rubilar et al. (2013) and Albaugh et al. (2004). Briefly, a long-term experiment was established in order to examine the rotation effects of subsoiling, weed control and fertilization effects in radiata pine plantations. Soils at the site are andesiticbasaltic excessively drained dry sands. Meteorological records, available from a nearby weather station, indicate an average annual rainfall of $1230 \mathrm{~mm}_{\text {year }}{ }^{-1}$, ranging from $760 \mathrm{~mm}$ in 2010 to $2043 \mathrm{~mm}$ in 2002. Mean annual temperature recorded at the site was $13.7^{\circ} \mathrm{C}$. The area is a second rotation cutover, with a $14.9 \mathrm{~m}$ site index (20 years) and estimated first rotation productivity (24 years) of $7.8 \mathrm{~m}^{3}$.ha $\mathrm{ha}^{-1}$.year-1; the herbaceous competition was dominated by Rumex acetosella and Verbascum densiflorum, and common woody shrubs were Rubus ulmifolius and Baccharis linearis (Rubilar et al., 2013).

The original study investigated the effects and interaction of soil preparation (subsoiling), weed control up to 2 years, and fertilization treatments at establishment on radiata pine growth. Soil tillage treatments were randomly assigned and applied on main plots considering shovel planting (SO) and subsoiling + bedding \& shovel planting (S1). Main plots were split in four blocks, and a factorial combination of weed control (WO = no weed control, $W 1=2$-year banded weed control) and fertilization ( $F 0=$ boron at establishment vs $F 1=$ nitrogen, phosphorus and boron at establishment + nitrogen, phosphorus, potassium and boron after 2 years since planting) were allocated as subplots. Initial spacing at establishment was $4.0 \mathrm{x}$ $2.0 \mathrm{~m}$, totalizing 1250 trees ha ${ }^{-1}$. Treatment plots were 0.32 ha with an internal measurement plot of 100 trees plot $^{-1}$. The plantation was established in July 2000 with bare root radiata pine cuttings of an operational full-sib family. More details about the site and applied treatments can be found in Rubilar et al. (2013).

\subsection{Growth measurements}

Tree height and DBH (diameter at breast height, $1.35 \mathrm{~m}$ ) were measured annually since 2004 until 2012 for all trees in each measurement plot $\left(\sim 100\right.$ trees $\left.^{-10 t^{-1}}\right)$. Individual tree stem volume estimates were obtained considering the following local function (Equation 1), developed by Forestal Mininco Co. (1995): 
Where: Vol is individual tree volume $\left(\mathrm{m}^{3}\right), \mathrm{DBH}$ is diameter at breast height $(\mathrm{cm})$ and $\mathrm{H}_{\mathrm{t}}$ is tree height $(\mathrm{m})$.

\subsection{Remote Sensing data}

Eighteen raw Landsat 7 Enhanced Thematic Mapper Plus (ETM+) images (path 233, row 086) with a 30-meter pixel resolution were obtained from USGS archive (http://earthexplorer.usgs.gov) in September 2017 to calculate Spectral Vegetation Indices (SVIs) for each pixel from year 2001 to 2012 for the study area (Table 1). At least one image per year, between January and March, and with no clouds affecting reflectance values, was selected during this period.

Table 1. Summary of parameters of the Landsat 7 ETM+ satellite images used in the study

\begin{tabular}{cccccc}
\hline $\begin{array}{c}\text { Image Date }(\text { YY- } \\
\text { MM-DD) }\end{array}$ & $\begin{array}{c}\text { Sun Azimuth } \\
\left.\mathbf{(}^{\circ}\right)\end{array}$ & $\begin{array}{c}\text { Sun Elevation } \\
\left.\mathbf{(}^{\circ}\right)\end{array}$ & $\begin{array}{c}\text { Image Date } \\
(\text { YY-MM-DD) }\end{array}$ & $\begin{array}{c}\text { Sun } \\
\text { Azimuth } \\
\left({ }^{\circ}\right)\end{array}$ & $\begin{array}{c}\text { Sun } \\
\text { Elevation } \\
\left.\mathbf{(}^{\circ}\right)\end{array}$ \\
\hline $2001-02-14$ & 65.32 & 47.31 & $2007-11-14$ & 64.35 & 56.09 \\
$2001-10-12$ & 53.21 & 47.81 & $2008-03-05$ & 57.67 & 42.63 \\
$2002-02-01$ & 70.39 & 49.82 & $2008-10-31$ & 59.56 & 53.39 \\
$2002-08-12$ & 41.25 & 26.88 & $2009-02-20$ & 63.03 & 45.88 \\
$2003-02-20$ & 63.63 & 45.72 & $2010-02-23$ & 61.49 & 45.54 \\
$2004-02-23$ & 62.42 & 45.15 & $2010-09-19$ & 46.49 & 40.25 \\
$2005-02-09$ & 67.46 & 48.18 & $2011-01-09$ & 74.49 & 54.94 \\
$2006-02-28$ & 59.97 & 43.98 & $2011-09-06$ & 43.78 & 35.58 \\
$2007-03-03$ & 58.75 & 43.36 & $2012-01-28$ & 70.46 & 51.71 \\
\hline
\end{tabular}

Digital numbers (DNs) from the Landsat scene were converted to at-sensor spectral radiance, using the provided maximum and minimum radiance values delivered from each image. This procedure removes the gain and offset effects introduced by the image system (Chávez, 1996). Radiance values were converted to reflectance at the top of atmosphere (TOA). This procedure allows the comparison of different images because it corrects differences associated with different solar zenith angles and Earth-Sun distances due to the time difference between data acquisitions. It also compensates different values of exo-atmospheric solar irradiance for each band (Chander et al., 2009).

\subsection{Spectral Vegetation Indices}

From the atmospherically corrected reflectance values obtained through the processed data it was possible to calculate four different SVIs for the study plots. The calculation was performed using Equation 2 for NDVI, Equation 3 for SAVI, Equation 4 for SR and Equation 5 for RSR. In each plot, a $10 \mathrm{~m}$ buffer was considered to avoid influences from other treatments on reflectance estimates. Consequently, the final area for the plots was $60 \times 20$ meters, which included two to four independent pixels. Selected SVIs were calculated using three Landsat ETM spectral bands, including red (channel 3: 630-690 nm), NIR (channel 4: 760-900 nm) and SWIR (Short-wave Infrared - channel 5: 1550-1750 nm), displayed in the equations below: 


$$
\begin{aligned}
& \text { NDVI }=\frac{\rho_{4}-\rho_{3}}{\rho_{4}+\rho_{3}} \\
& \text { SAVI }=\frac{\left(1+L_{s}\right)\left(\rho_{4}-\rho_{3}\right)}{\left(L_{s}+\rho_{4}+\rho_{3}\right)} \\
& \operatorname{SR}=\frac{\rho_{4}}{\rho_{3}} \\
& \operatorname{RSR}=\frac{\rho_{4}}{\rho_{3}} \cdot \frac{\left(\rho_{5 \text { MAX }}-\rho_{5}\right)}{\left(\rho_{5 \text { MAX }}-\rho_{5 \text { MIN }}\right)}
\end{aligned}
$$

where

$\rho_{3}$ is band 3 reflectance;

$\rho_{4}$ is band 4 reflectance;

$\rho_{5}$ is band 5 reflectance;

$\rho_{5 \max }$ are the largest reflectance values for channel 5 covering the study area;

$\rho_{5 \min }$ are the smallest reflectance values for channel 5 covering the study area;

$L_{s}$ is a soil adjustment factor that varies from 0.25 to 0.75 , being 0.5 an accepted value for all soil types.

\subsection{Statistical analysis}

All statistical analyses were performed using the software R (R Core Team, 2017). Linearized logarithmic models (Gong; Pu; Miller, 1995; Chen; Cihlar, 1996), with volume and volume increment as independent variables (Equation 6), were used to analyze the relationships with each one of the SVIs. Each model considered the following mathematical expression:

$\mathrm{Y}=\mathrm{a}+\mathrm{b} \ln (\mathrm{x})$

where $Y$ represents the SVIs, $a$ and $b$ are regression coefficients and $x$ is the independent variable, represented, separately, by cumulative volume, MAI (mean annual increment) and CAI (current annual increment).

In order to account for estimates bias, the ratio between the root mean standard error (RMSE) and the mean of the SVIs was used as a residual analysis (also expressed as \%RMSE) (Turner et al., 1999; Gizachew et al., 2016). For each relationship, the coefficient of determination $\left(r^{2}\right)$ and the observed significance level ( $p$-value) were also considered to check the goodness of fit and statistical significance of the relationships as the best spectral vegetation index predictor to estimate wood production of the stand.

Regarding the comparison of SVIs response over time, Tukey's test was used on the basis of a $5 \%$ significance level, providing information about the difference between treatments.

In order to evaluate the potential relationships between stand uniformity and SVIs, a coefficient of variation (CV) of each SVI was calculated to evaluate the value of indirect assessments of stand variability (Rubilar et al., 2008). Analysis of the relationship between volume estimates variability with vegetation indices' coefficients of variation (CVs) were performed in order to explore their value as estimates of intrinsic spatial variation of stand production. For this comparison, mean annual CV values of volume and SVI were calculated for each evaluated treatment (with and without weed control). 


\section{RESULTS AND DISCUSSION}

\subsection{Cumulative and growth measurements}

Growth measurements showed that since the beginning of the experiment (one year after treatment) there were significant differences between plots with weed control (W1) and with no weed control (WO) (Figure 1). Mean volume response due to weed control was $2 \mathrm{~m}^{3}$ ha-1 at year 3 (a 485\% difference compared to the no-weed control treatment) and $35 \mathrm{~m}^{3} \mathrm{ha}^{-1}$ at year 11 (a 52\% difference). Fertilization and subsoiling treatments had no significant effects in stand growth; therefore only weed control effects were observed across treatment plots. These results corroborated preceding studies, which have shown the importance of early weed control in P. radiata, providing a large response in the tree growth when water limitations exist at Mediterranean climate sites (Kogan \& Figueroa, 1999; Rubilar et al., 2008). Large effects of weed control at these sites can be explained due to reductions in competition for water and light (Richardson et al., 1996) given the lack of response to nutrient additions.

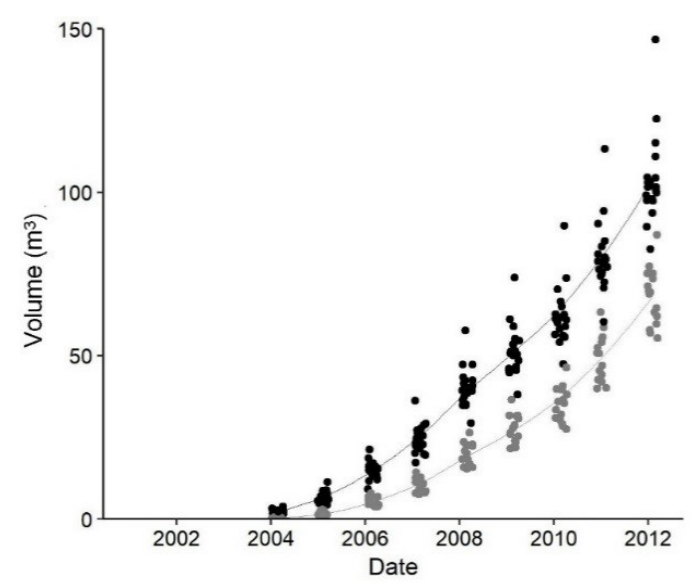

Figure 1. Accumulated volume $\left(\mathrm{m}^{3}\right)$ observed in the experimental trial for W1 (black dots) and W0 (gray dots) plots.

\subsection{SVIs response over time}

Vegetation indices values were calculated over time as shown in Figure 2. As of the second year, SVIs at the W1 treatment plots were significantly higher than at the W0 treatment plots, reaching a maximum difference of $18 \%$ for NDVI and SAVI, $21 \%$ for SR and $61 \%$ for RSR. The higher and statistically different ( $p$-value $<0.0001$ ) values of SVIs in W1, compared to W0 plots, followed the results observed for volume responses (Figure 1).

Since SVIs estimate LAl, our results are in agreement with other studies (Battaglia et al., 1998; Cohrs et al., 2020), which indicate that LAI is strongly related to forest growth and productivity. A comparison among SVIs showed differences in the quality of its relationship with volume growth. However, in general, all indices showed a stabilization after canopy closure age, matching an expected maximum stand LAI. For W1 plots, this was observed when the stand was 9 to 10 years old. In contrast, in WO plots, it was observed about 2 to 3 years later (Figure 2). This behavior can be explained considering the relationship between LAl and stand development, which tends to reach a maximum and decline after certain age, after which variations in leaf area are small and volume growth continues at a constant rate (Battaglia et al., 1998; Qiao et al., 2016). Nevertheless, it is also possible that the observed SVIs stabilization and the slight decline in all indices were due to changes in rainfall due to extreme drought events reported at the site. In fact, during year 2010, annual rainfall was 38\% lower than its average over the region, which may have directly influenced leaf area according to the 
studies by Grier \& Running (1977) and Luo et al. (2004), where LAl decreased with decreasing water availability.

Over time - at W1 and W0 plots - NDVI values ranged from 0.182 to 0.651 and from 0.197 to 0.632 , respectively. The lowest NDVI values were observed in the first year of the study, right after establishment. In the W1 plots, NDVI stabilization was reached around year 9 with a value close to 0.62 , while in the W0 plots a similar value was reached at approximately year 12 (Figure 2A). NDVI stabilization around 0.60 can be related to the saturation of this SVI, an issue that has been related to an underestimation of ecosystem productivity in dense biomass regions when NDVI has been correlated with LAI and forest productivity (Gu et al., 2013). Spanner et al. (1990) and Fassnacht et al. (1997) found saturation of NDVI for LAl estimation when this index reached a value of 0.80 for coniferous forests. Alvares et al. (2013) observed maximum values of NDVI close to 0.90 when analyzing the NDVI dynamics of Pinus taeda and Pinus caribaea var. hondurensis stands in Brazil. Since the maximum values for NDVI at age 11 were around 0.60 in our study, our estimates are less likely to have reached a saturation for NDVI.

SAVI had a similar behavior to NDVI, although it showed a narrower range of variation, ranging from 0.09 to 0.29 for W1 plots and from 0.10 to 0.31 for W0 plots (Figure 2B) and the lowest values were observed during the first year after establishment. The highest values were found when the stand was 10 years old for W1 plots, achieving an average SAVI of 0.28. For WO plots, the highest value was achieved at age 12, with an average of 0.26 . SAVI also presented a decline over time after achieving its maximum value. As NDVI, SAVI has been also reported in studies as an index that presents saturation at high biomass values (Xavier; Vettorazzi, 2004; Almeida et al., 2015). For Eucalyptus plantations in Brazil, Almeida et al. (2015) found saturation of SAVI for LAl estimation when values reached 0.45. At watershed-level, Xavier \& Vettorazzi (2004) also reported saturation of SAVI at high values of LAI (>3), achieving a maximum index of 0.5. However, Huete et al. (1997) did not find saturation of SAVI for forests in Brazil and Chile. Considering the maximum observed values found in our study, saturation was not reached for SAVI.

The SR values showed a wider range compared to NDVI and SAVI, ranging from 1.44 to 4.74 in W1 plots and from 1.49 to 4.44 in WO plots (Figure 2C). The lowest values were observed in the first year and the highest were found at age 11 for W0 and 7 for W1 plots. Differently from NDVI and SAVI, SR did not stabilize in WO plots over time. This behavior was observed by Chen \& Cihlar (1996) in coniferous forests, finding linear correlations between LAI and SR. In loblolly pine ( $P$. taeda) plantations, Flores (2003) also found linear correlations with maximum values of SR around 7 and indicating no-saturation conditions.

Finally, the RSR was the index with the highest difference in relation to response for weed control, with average differences of $35 \%$ over time. Its range was wider than SR, ranging from 0.03 to 4.61 in W1 plots and 0.07 to 3.17 in Wo plots (Figure 2D). Also, a higher plot variation was observed for this SVI when compared to other vegetation indices, presenting statistically significant differences starting in year 2 (Figure 2). While W1 plots achieved a maximum value at year 9 and afterwards a decline, W0 plots followed a continuous increase and showed no stabilization until year 12. These notorious differences can be explained through the addition of the shortwave 5 (SWIR) band to the SR index. As presented in Equation 5, the maximum and minimum reflected SWIR was considered in order to calculate the index. In addition, each plot had only 2 to 4 pixels, thus the impact of pixels which presented high values of reflectance in SWIR band may have caused the low values observed in the plots where they were located (usually WO plots). On the other hand, in plots where the difference of SWIR $\mathrm{max}_{\text {ax }}$ and SWIR was higher, RSR values were higher (normally in WO plots). This phenomenon is explained due to the relationship between SWIR and LAI, where low SWIR values are related to high LAI values (Brown et al., 2000). In what concerns the saturation aspect, Stenberg et al. (2004) found linear relationships between LAI and RSR for boreal coniferous forests. However, Brown et al. (2000) and Tian et al. (2007) found a saturation for LAl, close to 3.0 and $4.0 \mathrm{~m}^{2} / \mathrm{m}^{2}$, respectively.

Regarding the differences between the observed SVI values in the study, differences between W0 and W1 plots were found, at a 5 percent significance level, for NDVI and SR from 
year 3 to year 11; for SAVI from year 4 to year 11; and for RSR from year 2 to year 11 . However, in the 10-year measurement, these differences were not significant for NDVI, SAVI and SR, what may be explained by the reduction of annual rainfall in 2010 .
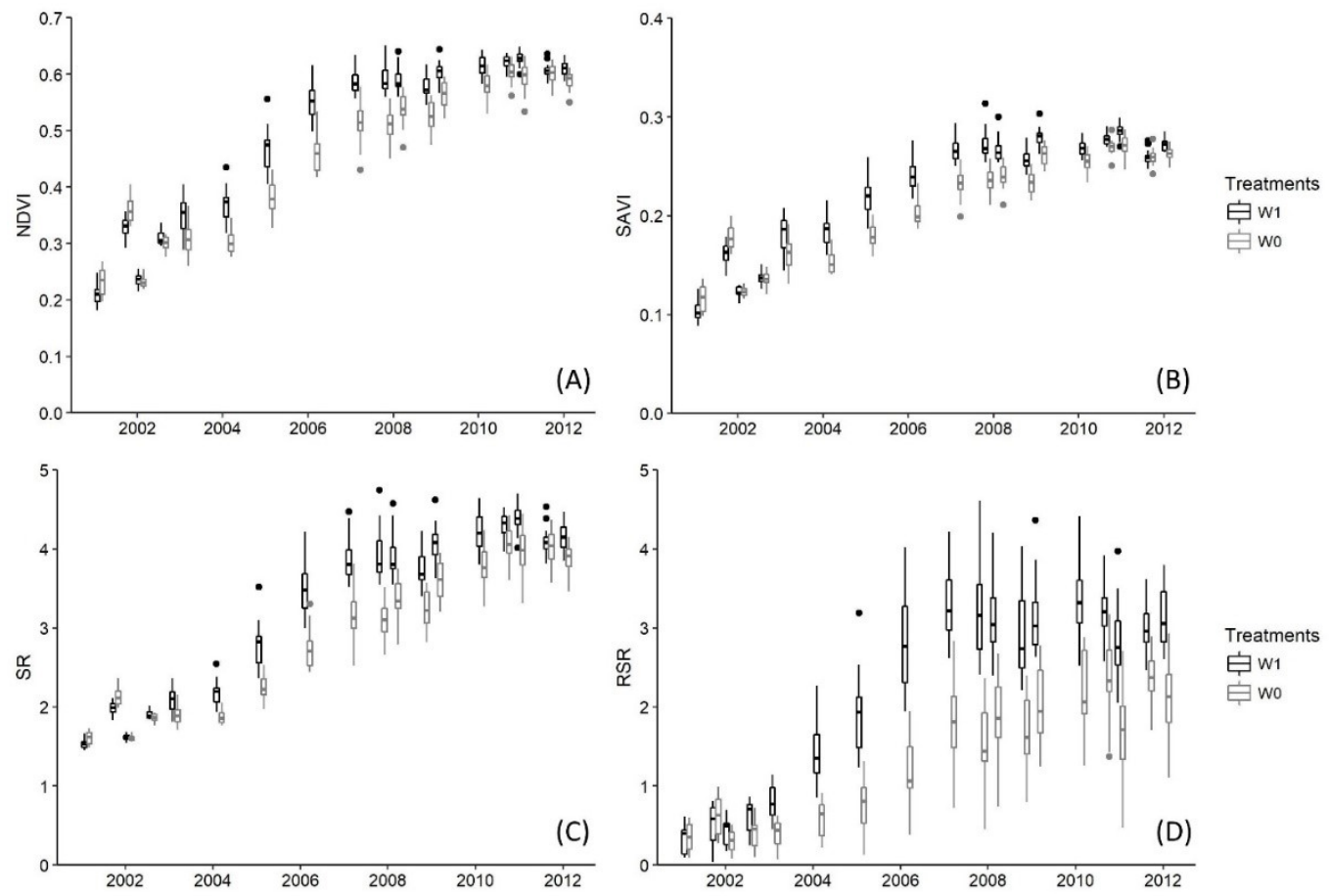

Figure 2. Comportment of NDVI (A), SAVI (B), SR (C) and RSR (D) over time, since the establishment. Black color represents W1 plots and gray color refers to W0 plots.

\subsection{Relationships between volume and SVIs}

All the spectral vegetation indices presented significant correlations with the volume, with $\mathrm{p}$-values lower than 0.0001 . However, they differed with respect to their fit and goodness of prediction (Table 2). NDVI and SAVI presented narrow ranges (respectively 0.18-0.65 and 0.090.31 ) across the range of volume values, but SR and RSR were more sensitive to volume variation, presenting ranges of 1.44-4.74 and 0.03-4.61, respectively.

Significant correlations for all SVIs are explained due to the strong relationship between leaf area index and stand growth, as presented in several studies involving volume $\left(\mathrm{m}^{3} \mathrm{ha}^{-1}\right.$ or $\left.\mathrm{m}^{3} \mathrm{ha}^{-1} \mathrm{yr}^{-1}\right)$, biomass $\left(\mathrm{Mg} \mathrm{ha}{ }^{-1}\right)$, ANPP (above ground net primary production - $\mathrm{Mg} \mathrm{ha}^{-1}$ ) or basal area growth $\left(\mathrm{cm}^{2} \mathrm{yr}^{-1}\right)$ with leaf area or leaf area index. In P. taeda stands in the US, Vose \& Allen (1988) found positive and linear correlations $\left(r^{2}=0.75, p<0.05\right)$ between stem wood growth ( $\mathrm{m}^{3} \mathrm{ha}^{-1} \mathrm{yr}^{-1}$ ) and LAl. Dalla Tea \& Jokela (1992); in Pinus taeda and Pinus elliottii stands in Argentina, linear and positive correlations were observed $\left(r^{2}=0.98\right.$, and $r^{2}=0.86, p<0.05$, respectively) between MAI and LAI. In Canada, Penner \& Deblonde (1996) related leaf area and basal area growth of Pinus resinosa and Pinus banksiana, finding significant correlations for both species. In radiata pine stands in New Zealand with different ages (between 7 and 17 years old), Beets \& Whitehead (1996) found significant linear relationship $\left(r^{2}=0.64, p=0.01\right)$ between LAl and biomass annual increment.

Accuracy of estimates represented by \%RMSE values found in our study showed two different patterns regarding SVIs. For NDVI, SAVI and SR, \%RMSE ranged from 0.05 to 0.09 , while RSR presented higher values, ranging from 0.27 to 0.31 , which indicates a poorest fit compared to other indices (Biudes et al., 2014). Similar results for NDVI, SAVI and SR were found by Dube \& Mutanga (2015), with \%RMSE values ranging from 0.12 to 0.14 , when analyzing relationships between SVIs and aboveground biomass in a P. taeda stand in South Africa. 
Table 2. Models, $r^{2}$, RMSE and \%RMSE for the volume-SVIs relationship, using different representations of volume (accumulated volume, CAI and MAI) and four SVIs (NDVI, SAVI, SR and RSR).

\begin{tabular}{lllll}
\hline \multicolumn{1}{c}{ Model } & $\mathbf{r}^{2}$ & RMSE & \%RMSE & p value \\
\hline Cumulative Volume & & & & \\
$\mathrm{NDVI}=0.0619 \ln (\mathrm{Vol})+0.3563$ & 0.92 & 0.03 & 0.05 & $<0.0001$ \\
$\mathrm{SAVI}=0.0248 \ln (\mathrm{Vol})+0.1717$ & 0.90 & 0.01 & 0.05 & $<0.0001$ \\
$\mathrm{SR}=0.4942 \ln (\mathrm{Vol})+2.0373$ & 0.88 & 0.27 & 0.08 & $<0.0001$ \\
$\mathrm{RSR}=0.4782 \ln (\mathrm{Vol})+0.8686$ & 0.54 & 0.66 & 0.29 & $<0.0001$ \\
Current Annual Increment & & & & \\
$\mathrm{NDVI}=0.0877 \ln (\mathrm{CAl})+0.3669$ & 0.79 & 0.03 & 0.06 & $<0.0001$ \\
$\mathrm{SAVI}=0.0374 \ln (\mathrm{CAl})+0.1702$ & 0.76 & 0.02 & 0.06 & $<0.0001$ \\
$\mathrm{SR}=0.78124 \ln (\mathrm{CAl})+1.9282$ & 0.75 & 0.31 & 0.09 & $<0.0001$ \\
$\mathrm{RSR}=0.5515 \ln (\mathrm{CAl})+0.8432$ & 0.43 & 0.69 & 0.31 & $<0.0001$ \\
Mean Annual Increment & & & & \\
NDVI $=0.0823 \ln (\mathrm{MAl})+0.4516$ & 0.91 & 0.03 & 0.05 & $<0.0001$ \\
$\mathrm{SAVI}=0.0330 \ln (\mathrm{MAl})+0.2097$ & 0.89 & 0.01 & 0.05 & $<0.0001$ \\
$\mathrm{SR}=0.6521 \ln (\mathrm{MAl})+2.8025$ & 0.86 & 0.29 & 0.08 & $<0.0001$ \\
$\mathrm{RSR}=0.6820 \ln (\mathrm{MAl})+1.5570$ & 0.61 & 0.60 & 0.27 & $<0.0001$ \\
\hline
\end{tabular}
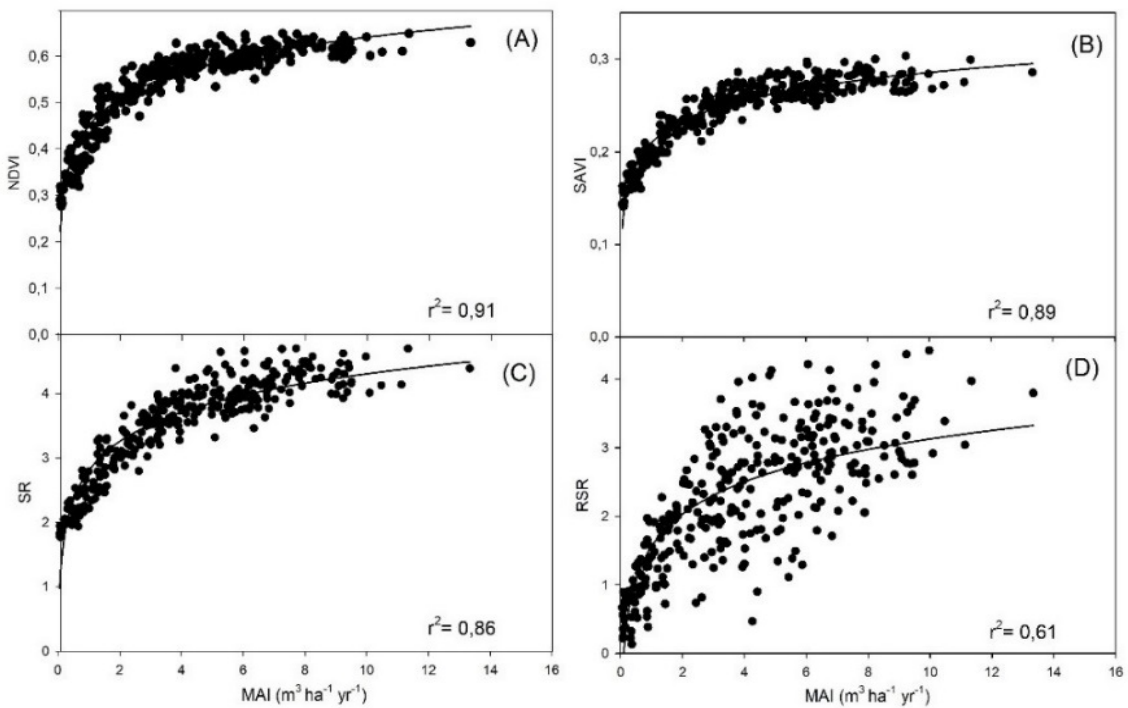

Figure 3. Relationship between NDVI (A), SAVI (B), SR (C) and RSR (D) and annual stem-wood volume growth.

Comparing all volume parameters analyzed in our study, the one which presented the lowest \%RMSE values was MAI. It presented the smallest \%RMSE values for all the SVIs and relationships are shown in Figure 3. Our analyses of all SVIs indicated that NDVI showed the best correlations with cumulative volume, CAI and MAI reaching $r^{2}$ values of $0.917,0.787$ and 0.908 , respectively (Table 2). This positive relationship confirms the results found by Alvares et al. (2013) with P. taeda and P. caribaea var. hondurensis in Brazil and by Wang et al. (2004) with natural vegetation in USA. These authors found high correlations between NDVI and productivity, both at stand and individual tree levels. González-Alonso et al. (2006) 
observed a linear relationship $\left(r^{2}=0.79-0.82\right)$ between NDVI and stem volume $\left(\mathrm{m}^{2} \mathrm{ha}^{-1}\right)$ in a pine forest in Spain. However, in sparse semi-arid vegetation for the same region, NDVI did not present robust correlations with biomass (Hurcom \& Harrison, 1998). Evaluating the relationships between NDVI and biomass in different types of vegetation, Zheng et al. (2004) and Mašková et al. (2008), have found $r^{2}$ values ranging from 0.51-0.86. However, saturation of NDVI has been reported under high biomass accumulation conditions (Huete et al., 1997). This particular issue may limit NDVI as a useful index to be correlated with productivity when forest stands reach higher LAl values after canopy closure, thus leading to a potential underestimation of ecosystem productivity (Gu et al., 2013).

SAVI presented a good correlation with stand growth, being the second index with the highest $r^{2}$ for all evaluated parameters ( 0.896 for accumulated volume, 0.758 for CAI and 0.894 for MAI) (Table 2). Several studies have evaluated the relationship between SAVI and green aboveground biomass, mainly at biomes where soil has shown effects on reflectance values, such as deserts and arid grasslands (Ren \& Zhou, 2014). In tropical forests in Brazil, Araujo et al. (2000) found strong linear relationships $\left(r^{2}=0.80\right)$ between SAVI and stand biomass. A similar result was obtained by Gizachew et al. (2016) in low-biomass woodlands in Tanzania, who found a good linear relationship between total living biomass with a coefficient of determination of 0.49 and $p$-value $<0.005$. Regardless the high correlation with volume, SAVI may be presenting saturation problems similarly to NDVI at high biomass (Prabhakara et al., 2015). Therefore, the use of SAVI may be problematic at a more advanced age, when biomass accumulation reaches higher values.

SR, similarly to NDVI and SAVI, also presented high coefficients of correlation for accumulated volume, CAI and MAI $(0.883,0.751$ and 0.865 , respectively) (Table 2$)$, similarly to other studies. In fact, comparing different SVIs in a mountain birch forest in Finland, and their relationships with aboveground biomass, Heiskanen (2006) found the strongest linear relationships using SR $\left(r^{2}=0.81\right)$. Similar results were also obtained by Liu et al. (2006) in a logarithmic model $\left(r^{2}=0.73\right)$ relating SR and biomass in China. Although SR did not present the highest coefficients of correlation or the lowest \%RMSE, this index showed a higher potential as a robust estimator of forest productivity at high leaf area or biomass accumulation levels. In fact, studies (Running et al., 1986; Flores et al., 2006) have reported that SR presents less saturation and broader responses across a broader range of LAI than NDVI and SAVI, a key consideration to predict forest productivity (Stenberg et al., 2004).

Compared to the other indices, RSR performed the lowest $r^{2}$ values (ranging from 0.425 to 0.607 ) (Table 2). These poorer correlations were caused by the high variation found in RSR, probably due to the addition of the SWIR band as discussed previously. However, a study carried out in boreal forest stands in Finland (Majasalmi \& Rautiainen, 2016), found a poorer relationship $\left(r^{2}=0.21\right)$ between RSR and above ground biomass compared to our study. Although RSR, similarly to SR, has a wider range of values in comparison with NDVI and SAVI, it was not a good index to explain stand volume variation.

\subsection{Relationships with stand quality}

Stand homogeneity is a key indicator of stand quality. Studies have observed that final productivity of a forest stand is highly related to stand uniformity (Stape et al., 2010). Silvicultural operations, such as fertilization, weed control and soil preparation (Hakamada et al., 2015) influence stand uniformity. In addition, stand uniformity is critical for forest planning activities such as thinning, pruning and harvesting (Ortega et al., 2002).

Volume variability expressed by CV differences between treatments (weed control vs no weed control) were evaluated by analyses of SVIs' CVs as indicators of stand uniformity. Estimates of volume CV over time in W1 plots were generally lower than in W0 plots (Figure 4). Similar results have been found for Eucalyptus in South Africa, when analyzing the impact of weed control treatments on the stand uniformity and volume of Eucalyptus plantations (Little et al., 2003). Our results suggest that stand variability may be explored using CV values 
from remote sensing and support local selection of inventory plots or provide a framework for stand forest assessments using SVIs spatial variability.

A strong relationship between any of the evaluated SVI's CVs and volume CV was not found (Figure 4). Possibly, this result is due to the small number of pixels that constitutes each plot, ranging from 2 to 4 different pixels, only. However, although the indices did not present a strong correlation with homogeneity in this study, they should be considered for larger areas, since a small number of pixels for each plot may have limited our ability to understand stand spatial variation in wood production. Also, sensors with a higher spatial resolution may provide consistent estimates of stand uniformity predictors using SVIs.
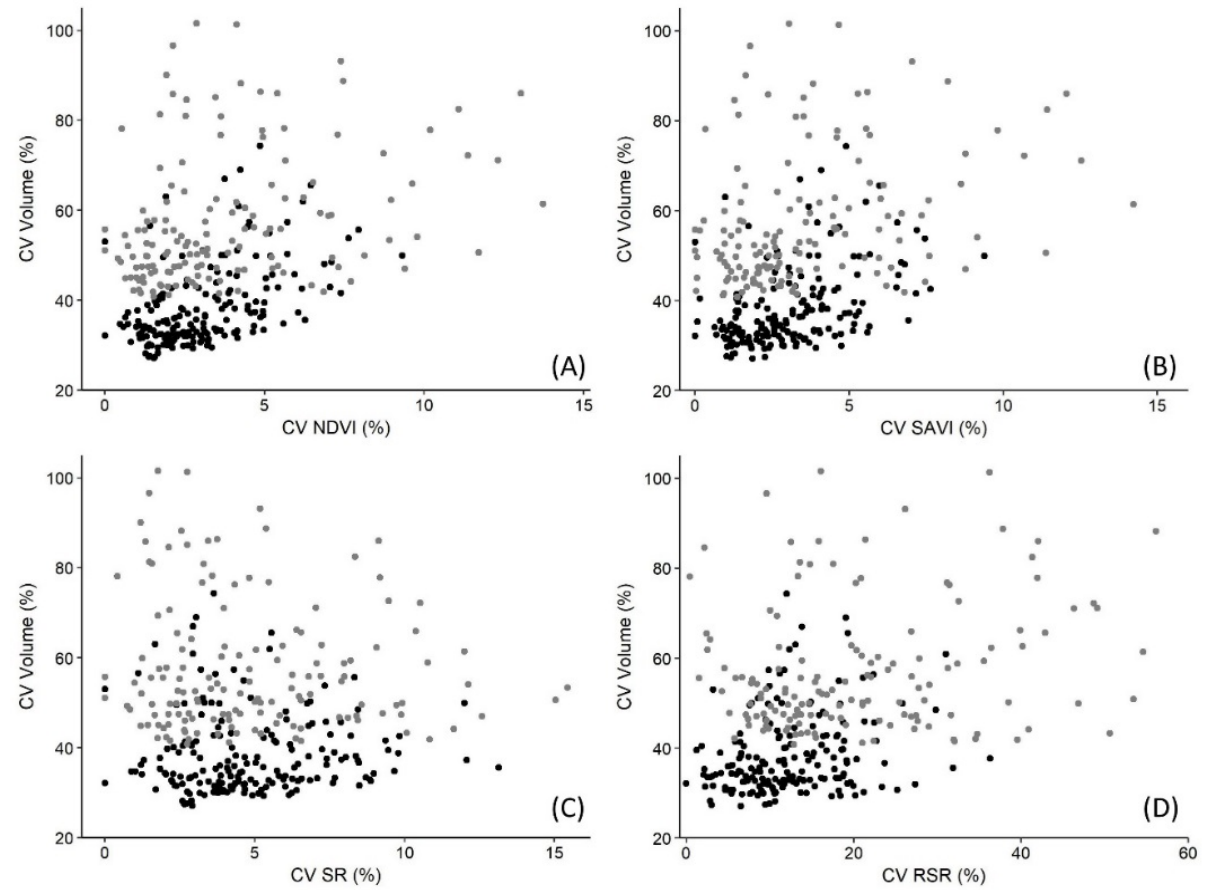

Figure 4 Coefficient of variation of volume and of NDVI (A), SAVI (B), SR (C) and RSR (D) over time. Black dots represent $\mathrm{W} 1$ plots and gray dots refer to W0 plots.

\section{CONCLUSIONS}

The stand presented significant differences in volume estimates between plots with weed control versus plots without weed control. This difference was effectively captured by the vegetation indices over time, thus demonstrating how accurate this tool can be.

All the spectral vegetation indices presented significant correlations with cumulative volume of the stand over time enabling its estimation in an effective way through satellite images. Among the evaluated indices, NDVI presented the highest correlations at the initial stand ages, however SR presented the highest potential for evaluations over time when biomass achieved higher cumulative values.

Although no significant relationships were found for vegetation indices in relation to stand volume variability, improved assessments may detect and evaluate spatial forest variability. Future studies should consider larger areas or sensors with a higher spatial resolution order to evaluate these estimates.

SVIs are dynamic tools that can provide valuable information to monitor forest growth and stand variability. Integrating these indices into empirical and process-based models considering water, soil and climatic variables may be an important tool for advancing on precision silviculture of forest stands. 


\section{REFERENCES}

Albaugh, T. J., Rubilar, R., Alvarez, J., \& Allen, H. L. (2004). Radiata pine response to tillage, fertilization, and weed control in Chile. Bosque (Valdivia), 25(2), 5-15. http://dx.doi.org/10.4067/S071792002004000200002.

Almeida, A. Q., Ribeiro, A., Delgado, R. C., Rody, Y. P., Oliveira, A. S., \& Leite, F. P. (2015). Índice de área foliar de eucalyptus estimado por índices de vegetação utilizando imagens TM - landsat 5. Floresta e Ambiente, 22(3), 368-376. http://dx.doi.org/10.1590/2179-8087.103414.

Alvares, C. A., Munhoz, J. S. B., Stape, J. L., Stahl, J., Andrade, L., Santos, G., Lima, R., Coutinho, R. T., Hoinacki, R., \& Fox, T. (2013, Abril 13-18). Caracterização da dinâmica dos índices de vegetação NDVI e EVI em plantações de Pinus do Brasil. In Anais XVI Simposio Brasileiro de Sensoriamento Remoto - SBSR (pp. 2866-2873). Foz do Iguaçu, PR: INPE.

Araujo, L. S., Santos, J. R., \& Shimabukuro, Y. E. (2000). Relationship between SAVI and biomass data of forest and savanna contact zone in the brazilian Amazonia. International Archives of Photogrammetry and Remote Sensing, 33(Part B7), 77-81.

Battaglia, M., Cherry, M. L., Beadle, C. L., Sands, P. J., \& Hingston, A. (1998). Prediction of leaf area index in eucalypt plantations: effects of water stress and temperature. Tree Physiology, 18(November), 521-528. PMid:12651338. http://dx.doi.org/10.1093/treephys/18.8-9.521.

Beets, P. N., \& Whitehead, D. (1996). Carbon partitioning in Pinus radiata stands in relation to foliage nitrogen status. Tree Physiology, 16(1-2), 131-138. PMid:14871756. http://dx.doi.org/10.1093/treephys/16.1-2.131.

Berger, R., Silva, J. A. A., Ferreira, R. L. C., Candeias, A. L. B., \& Rubilar, R. (2019). Vegetation indices for the leaf area index estimation in clonal plantations of Eucalyptus saligna Smith. Ciência Florestal, 29(2), 885. http://dx.doi.org/10.5902/1980509816942.

Biudes, M. S., Machado, N. G., Danelichen, V. H. M., Souza, M. C., Vourlitis, G. L., \& Nogueira, J. S. (2014). Ground and remote sensing-based measurements of leaf area index in a transitional forest and seasonal flooded forest in Brazil. International Journal of Biometeorology, 58(6), 1181-1193. PMid:23943204. http://dx.doi.org/10.1007/s00484-013-0713-4.

Brown, L., Chen, J. M., Leblanc, S. G., \& Cihlar, J. (2000). A shortwave infrared modification to the simple ratio for LAI retrieval in boreal forests: an image and model analysis. Remote Sensing of Environment, 71(1), 16-25. http://dx.doi.org/10.1016/S0034-4257(99)00035-8.

Chander, G., Markham, B. L., \& Helder, D. L. (2009). Summary of current radiometric calibration coefficients for Landsat MSS, TM, ETM+, and EO-1 ALI sensors. Remote Sensing of Environment, 113(5), 893-903. http://dx.doi.org/10.1016/j.rse.2009.01.007.

Chávez, P. S. J. (1996). Image-based atmospheric corrections - Revisited and improved. Photogrammetric Engineering and Remote Sensing, 62(9), 1025-1036.

Chen, J. M., \& Cihlar, J. (1996). Retrieving leaf area index of boreal conifer forests using landsat TM images. Remote Sensing of Environment, 55(2), 153-162. http://dx.doi.org/10.1016/00344257(95)00195-6.

Cohrs, C. W., Cook, R. L., Gray, J. M., \& Albaugh, T. J. (2020). Sentinel-2 Leaf Area Index Estimation for Pine Plantations in the Southeastern United States. Remote Sensing, 12(9), 1406. http://dx.doi.org/10.3390/rs12091406.

Dalla Tea, F., \& Jokela, E. J. (1992). Estimación del índice de área foliar en plantaciones de Pinus elliottii var. elliottii y Pinus taeda. Investigación agraria. Sistemas y recursos forestales, 1(2), 123-136.

Dube, T., \& Mutanga, O. (2015). Evaluating the utility of the medium-spatial resolution Landsat 8 multispectral sensor in quantifying aboveground biomass in uMgeni catchment, South Africa. ISPRS Journal of Photogrammetry and Remote Sensing, 101, 36-46. http://dx.doi.org/10.1016/j.isprsjprs.2014.11.001.

Fassnacht, K. S., Gower, S. T., Mackenzie, M. D., Nordheim, E. V., \& Lillesand, T. M. (1997). Estimating the leaf area index of North Central Wisconsin forests using the landsat thematic mapper. Remote Sensing of Environment, 61(2), 229-245. http://dx.doi.org/10.1016/S0034-4257(97)00005-9.

Flores, F. J. (2003). Using remote sensing data to estimate leaf area index and foliar nitrogen of loblolly pine plantations (Dissertation). Graduate Faculty, North Carolina State University, Raleigh, NC.

Flores, F. J., Allen, H. L., Cheshire, H. M., Davis, J. M., Fuentes, M., \& Kelting, D. (2006). Using multispectral satellite imagery to estimate leaf area and response to silvicultural treatments in loblolly pine stands. Canadian Journal of Forest Research, 36(6), 1587-1596. http://dx.doi.org/10.1139/x06-030.

Forestal Mininco Co. (1995). Inventory and Mensuration Unit. Local function. [s.I.] 
Francis, C. A., Rutger, J. N., \& Palmer, A. F. E. (1969). A rapid method for plant leaf area estimation in Maize (Zea mays L.)1. Crop Science, 9(5), 537-539. http://dx.doi.org/10.2135/cropsci1969.0011183X000900050005x.

Gizachew, B., Solberg, S., Næsset, E., Gobakken, T., Bollandsås, O. M., Breidenbach, J., Zahabu, E., \& Mauya, E. W. (2016). Mapping and estimating the total living biomass and carbon in low-biomass woodlands using Landsat 8 CDR data. Carbon Balance and Management, 11(1), 13. PMid:27418944. http://dx.doi.org/10.1186/s13021-016-0055-8.

Gong, P., Pu, R., \& Miller, J. R. (1995). Estimation index area forest leaf coniferous uslng transect along the Oregon data Imager airborne Spectrogtaphic Compact. Photogrammetric Engineering and Remote Sensing, 61(9), 1107-1117.

González-Alonso, F., Merino-De-Miguel, S., Roldán-Zamarrón, A., García-Gigorro, S., \& Cuevas, J. M. (2006). Forest biomass estimation through NDVI composites. The role of remotely sensed data to assess Spanish forests as carbon sinks. International Journal of Remote Sensing, 27(24), 5409-5415. http://dx.doi.org/10.1080/01431160600830748.

Grier, C. G., \& Running, S. W. (1977). Leaf area of mature northwestern coniferous forests: relation to site water balance. Ecology, 58(4), 893-899. http://dx.doi.org/10.2307/1936225.

Gu, Y., Wylie, B. K., Howard, D. M., Phuyal, K. P., \& Ji, L. (2013). NDVI saturation adjustment: A new approach for improving cropland performance estimates in the Greater Platte River Basin, USA Ecological Indicators, 30, 1-6. http://dx.doi.org/10.1016/j.ecolind.2013.01.041.

Hakamada, R. E., Stape, J. L., Lemos, C. C. Z., Almeida, A. E. A., \& Silva, L. F. (2015). Uniformidade entre árvores durante uma rotação e sua relação com a produtividade em Eucalyptus clonais. Cerne, 21(3), 465-472. http://dx.doi.org/10.1590/01047760201521031716.

Heiskanen, J. (2006). Estimating aboveground tree biomass and leaf area index in a mountain birch forest using ASTER satellite data. International Journal of Remote Sensing, 27(6), 1135-1158. http://dx.doi.org/10.1080/01431160500353858.

Huete, A. R. (1988). A soil-adjusted vegetation index (SAVI). Remote Sensing of Environment, 25(3), 295309. http://dx.doi.org/10.1016/0034-4257(88)90106-X.

Huete, A. R., Liu, H., \& Van Leeuwen, W. J. D. (1997, August 3-8). The use of vegetation indices in forested regions: issues of linearity and saturation In Proceedings of the 1997 IEEE International Geoscience and Remote Sensing Symposium (pp. 1966-1968). Singapoure: IEEE.

Hurcom, S. J., \& Harrison, A. R. (1998). The NDVI and spectral decomposition for semi-arid vegetation abundance estimation. International Journal of Remote Sensing, 19(16), 3109-3125. http://dx.doi.org/10.1080/014311698214217.

Jordan, C. F. (1969). Derivation of leaf-area index from quality of light on the forest floor. Ecology, 50(4), 663-666. http://dx.doi.org/10.2307/1936256.

Kogan, M., \& Figueroa, R. (1999). Interferencia producida por las malezas durante los dos primeros años en Pinus radiata D. Don. Bosque (Valdivia), 20(1), 57-64. http://dx.doi.org/10.4206/bosque.1999.v20n1-06.

Le Maire, G., Marsden, C., Nouvellon, Y., Stape, J. L., \& Ponzoni, F. J. (2012). Calibration of a speciesspecific spectral vegetation index for leaf area index (LAI) monitoring: example with MODIS reflectance time-series on eucalyptus Plantations. Remote Sensing, 4(12), 3766-3780. http://dx.doi.org/10.3390/rs4123766.

Little, K. M., Van Staden, J., \& Clarke, G. P. Y. (2003). Eucalyptus grandis x E. camaldulensis variability and intra-genotypic competition as a function of different vegetation management treatments. New Forests, 25(3), 227-242. http://dx.doi.org/10.1023/A:1022901019080.

Liu, W., Gao, W., Gao, Z., \& Wang, X. (2006 September 27). Correlation analysis between the biomass of oasis ecosystem and the vegetation index at Fukang. In: Preceedings of SPIE - The International Society for Optical Engineering, San Diego, California. http://dx.doi.org/10.1117/12.678178.

Luo, T., Pan, Y., Ouyang, H., Shi, P., Luo, J., Yu, Z., \& Lu, Q. (2004). Leaf area index and net primary productivity along subtropical to alpine gradients in the Tibetan Plateau. Global Ecology and Biogeography, 13(4), 345-358. http://dx.doi.org/10.1111/j.1466-822X.2004.00094.x.

Majasalmi, T., \& Rautiainen, M. (2016). The potential of Sentinel-2 data for estimating biophysical variables in a boreal forest: A simulation study. Remote Sensing Letters, 7(5), 427-436. http://dx.doi.org/10.1080/2150704X.2016.1149251.

Mašková, Z., Zemek, F., \& Květ, J. (2008). Normalized difference vegetation index (NDVI) in the management of mountain meadows. Boreal Environment Research, 13(5), 417-432. 
Ortega, J. A., Foster, W., \& Ortega, R. (2002). Definición de sub-rodales para una silvicultura de precisión: una aplicación del método fuzzy k-means. Ciencia e Investigación Agraria, 29(1), 35-44. http://dx.doi.org/10.7764/rcia.v29i1.422.

Peduzzi, A., Wynne, R. H., Fox, T. R., Nelson, R. F., \& Thomas, V. A. (2012). Estimating leaf area index in intensively managed pine plantations using airborne laser scanner data. Forest Ecology and Management, 270, 54-65. http://dx.doi.org/10.1016/j.foreco.2011.12.048.

Penner, M., \& Deblonde, G. (1996). The relationship between leaf area and basal area growth in jack and red pine trees. Forestry Chronicle, 72(2), 170-175. http://dx.doi.org/10.5558/tfc72170-2.

Prabhakara, K., Hively, W. D., \& McCarty, G. W. (2015). Evaluating the relationship between biomass, percent groundcover and remote sensing indices across six winter cover crop fields in Maryland, United States. International Journal of Applied Earth Observation and Geoinformation, 39, 88-102. http://dx.doi.org/10.1016/j.jag.2015.03.002.

Qiao, H., Wu, M., Shakir, M., Wang, L., Kang, J., \& Niu, Z. (2016). Classification of small-scale eucalyptus plantations based on NDVI time series obtained from multiple high-resolution datasets. Remote Sensing, 8(2), 1-20. http://dx.doi.org/10.3390/rs8020117.

$\mathrm{R}$ Core Team (2017). R: A language and environment for statistical computing. Vienna, Austria: $\mathrm{R}$ Foundation for Statistical Computing. Retrieved in 2017, November 15, from https://www.rproject.org/

Ren, H., \& Zhou, G. (2014). Determination of green aboveground biomass in desert steppe using littersoil-adjusted vegetation index. European Journal of Remote Sensing, 47(1), 611-625. http://dx.doi.org/10.5721/EuJRS20144734.

Richardson, B., Vanner, A., Ray, J., Davenhill, N., \& Coker, G. (1996). Mechanisms of Pinus radiata growth suppression by some common forest weed species. New Zealand Journal of Forestry Science, 26(3), 421-437.

Rouse, R. W. H., Haas, J. A. W., \& Deering, D. W. (1973). Monitoring Vegetation Systems in the Great Plains with ERTS. In: S. C. Freden, E. P. Mercanti, \& M. A. Becker. 3rd Earth Resources Technology Satellite-1 Symposium- Volume I: Technical Presentations. NASA SP-351 (p. 309). Washington, D.C.: NASA.

Rubilar, R. A., Albaugh, T. J., Allen, H., Alvarez, J., Fox, T. R., \& Stape, J. L. (2013). Foliage development and leaf area duration in Pinus radiata. Forest Ecology and Management, 304, 455-463. http://dx.doi.org/10.1016/j.foreco.2013.05.044.

Rubilar, R. A., Lee Allen, H., Fox, T. R., Cook, R. L., Albaugh, T. J., \& Campoe, O. C. (2018). Advances in silviculture of intensively managed plantations. Current Forestry Reports, 4(1), 23-34. http://dx.doi.org/10.1007/s40725-018-0072-9.

Rubilar, R., Blevins, L., Toro, J., Vita, A., \& Muñoz, F. (2008). Early response of Pinus radiata plantations to weed control and fertilization on metamorphic soils of the Coastal Range, Maule Region, Chile. Bosque (Valdivia), 29(1), 74-84. http://dx.doi.org/10.4067/S0717-92002008000100009.

Running, S. W., Peterson, D. L., Spanner, M. A., \& Teuber, K. B. (1986). Remote sensing of coniferous leaf area. Ecology, 67(1), 273-276. http://dx.doi.org/10.2307/1938532.

Spanner, M. A., Pierce, L. L., Peterson, D. L., \& Running, S. W. (1990). Remote sensing of temperate coniferous forest leaf area index the influence of canopy closure, understory vegetation and background reflectance. International Journal of Remote Sensing, 11(1), 95-111. http://dx.doi.org/10.1080/01431169008955002.

Stape, J. L., Binkley, D., Ryan, M. G., Fonseca, S., Loos, R. A., Takahashi, E. N., Silva, C. R., Silva, S. R., Hakamada, R. E., Ferreira, J. M. de A., Lima, A. M. N., Gava, J. L., Leite, F. P., Andrade, H. B., Alves, J. M., Silva, G. G. C., \& Azevedo, M. R. (2010). The Brazil Eucalyptus Potential Productivity Project: influence of water, nutrients and stand uniformity on wood production. Forest Ecology and Management, 259(9), 1684-1694. http://dx.doi.org/10.1016/j.foreco.2010.01.012.

Stenberg, P., Rautiainen, M., Manninen, T., Voipio, P., \& Smolander, H. (2004). Reduced simple ratio better than NDVI for estimating LAI in Finnish pine and spruce stands. Silva Fennica, 38(1), 3-14. http://dx.doi.org/10.14214/sf.431.

Tian, Q., Luo, Z., Chen, J. M., Chen, M., \& Hui, F. (2007). Retrieving leaf area index for coniferous forest in Xingguo County, China with Landsat ETM+ images. Journal of Environmental Management, 85(3), 624627. PMid:17169482. http://dx.doi.org/10.1016/j.jenvman.2006.05.021.

Turner, D., Cohen, W. B., Kennedy, R. E., Karin, S., Fassnacht, T., \& Briggs, J. M. (1999) Relationships between Leaf Area Index and Landsat TM Spectral Vegetation Indices across Three Temperate Zone Sites. Remote Sensing of Environment, 70(1), 52-68. http://dx.doi.org/10.1016/S0034-4257(99)00057-7. 
Viganó, H. A., Borges, E. F., \& Franca-Rocha, W. J. S. (2011). Análise do desempenho dos Índices de Vegetação NDVI e SAVI a partir de imagem Aster. In: Anais XV Simpósio Brasileiro de Sensoriamento Remoto - SBSR (pp. 1828-1834). São José dos Campos, SP: INPE.

Vose, J. M., \& Allen, H. L. (1988). Leaf area, stemwood growth, and nutrition relationships in loblolly pine. Forest Science, 34(3), 547-563.

Wang, J., Rich, P. M., Price, K. P., \& Kettle, W. D. (2004). Relations between NDVI and tree productivity in the central Great Plains. International Journal of Remote Sensing, 25(16), 3127-3138. http://dx.doi.org/10.1080/0143116032000160499.

Xavier, A. C., \& Vettorazzi, C. A. (2004). Mapping leaf area index through spectral vegetation indices in a subtropical watershed. International Journal of Remote Sensing, 25(9), 1661-1672. http://dx.doi.org/10.1080/01431160310001620803.

Yang, H., Yang, X., Heskel, M., Sun, S., \& Tang, J. (2017). Seasonal variations of leaf and canopy properties tracked by ground-based NDVI imagery in a temperate forest. Scientific Reports, 7(1), 1-10. PMid:28455492. http://dx.doi.org/10.1038/s41598-017-01260-y.

Zheng, D., Rademacher, J., Chen, J., Crow, T., Bresee, M., Le Moine, J., \& Ryu, S. R. (2004). Estimating aboveground biomass using Landsat 7 ETM+ data across a managed landscape in northern Wisconsin, USA. Remote Sensing of Environment, 93(3), 402-411. http://dx.doi.org/10.1016/j.rse.2004.08.008.

Authors' contributions: VVB: Conceptualization, Methodology, Writing - original draft, Formal analysis, Investigation, Data curation, Visualization; RAR: Conceptualization, Methodology, Writing - review \& editing, Supervision, Project administration, Resources; RLC: Project administration, Resources; OCC: Project administration, Resources; DRC: Project administration, Resources; OM: Project administration, Resources. 